\title{
Chapter 7 \\ Sojourners in a New Land: Hope \\ and Adaptive Traditions
}

\author{
Kristina J. Peterson
}

\begin{abstract}
Somos el barco, somos el mar,
Yo navego en $t i$, tu navegas en mi

We are the boat, we are the sea, I sail in you, you sail in me

The boat we are sailing in was built by many hands

And the sea we are sailing on, it touches every land-chorus

So with our hopes we set the sails and face the winds once more

And

with our hearts we chart the waters never sailed before - chorus

Lorre Wyatt (1983)
\end{abstract}

\subsection{Introduction}

The Louisiana State flag has a mother Pelican caring for and protecting the next generation. Like the pelican on the flag, the task in Louisiana is to provide care for and protection of generations yet to come. The task facing us now, however, is rejuvenating rural communities that are suffering from inadequate physical and social structures. This rejuvenation will benefit and heal the current communities as they prepare to become areas of hospitality for those who are and will become sojourners from Louisiana coastal and riverine areas. At the core of hospitality of receiving the stranger are the acts of welcoming, supplying food, storytelling, and relationship and community building (Buber 1970). Culture, which includes "art and literature, lifestyles, ways of living together, value systems, traditions, and beliefs," is an overlooked element in rebuilding cities and rural areas, ravaged by disasters, war, and other forms of distress, according to a joint World Bank and UNESCO report (UNESCO 2018). This chapter explores the role of culture in the resettlement inland of coastal Louisianans.

\footnotetext{
K. J. Peterson ( $\square)$

Lowlander Center, Gray, LA, USA

e-mail: Kristina@lowlandercenter.org
} 
Humans are now in a new and critically different relationship with the world (Morton 2013). Called the "new anthropocene era," it is a relationship where human activity impacts the world at a planetary level seen most clearly in both slow and sudden weather events contributing to drastic shifts in population (Hawken 2017). In this new era, a radical extension of hospitality will be a necessity (Newman 2007). This new and radical hospitality will involve hosting and showing appreciation for all life, not just humans (Ogletree 2003; Morton 2017).

The 2016 floods confirmed that most of Louisiana is at risk to riverine, extreme rain events, and coastal flooding. As the population of the state works to adapt to the changing geography of and increased risks of such extreme weather, there will be shifts in living patterns and reworked understandings of dwelling place or home place (Brown 2011). The relocation of Louisiana coastal residents is already taking place (Dalbom et al. 2014). The research that has been done helps to understand internal post-disaster displacement but has focused mostly on urban areas. Little attention has been given to internally displaced rural communities and to the rural receiving communities (Hauer 2017).

Historically, individuals, households, neighborhoods, and communities do not “just pick up and move." Relocation is usually spurred by some critical need or set of circumstances that ends in the difficult choice of leaving a home place to become landless and placeless (Fullilove 2004). To experience the extremes of diaspora, or sojourning, it is most likely that all other resources or options for staying have been exhausted before leaving. The out-migration is likely to happen in stages as serial events prompt such personally critical decisions at each juncture. The lack of justice or the transgressions against justice are often connected with the impetus for going in many migration situations. Leaving becomes a hope that the situation might change and provide a just future in the new locale. It is imperative that the sojourner not be considered an object of charity, but a full and just participant in the new community. Notably for people in a deeply religious state (Cooperman 2015), the Bible addresses very similar circumstances. The principle from Judaic law that the sojourner must not be deprived of justice and be paid fair wages is apropos for Louisiana (Smith-Christopher 2002). Thus, for the receiving community to be ready to extend hospitality, it must first be healed or made whole by having obtained justice and economic security itself (Rom-Shiloni 2013; Escobar 2008). This chapter explores the possibilities for "just" sojourning and radical hospitality. Addressing immediate needs while understanding long-term implications of current choices and decisions involves creative living, hope, and a massive scale of collaboration and cooperation, brought together under a comprehensive state master plan of rejuvenation. A visionary plan will call upon the work of the various communities in the state to create real, appropriately aspirational rejuvenating designs. After all, we, through our history, were all once sojourners (Brasseaux and Davis 2017).

The first part of this chapter will highlight the challenges, or so-called wicked problems (Rittel and Webber 1973), facing people who live in receiving regions. Communities receiving the newcomers face not only the problems of extending services to the new arrivals but doing so in the context of chronic and layered problems that already make their home places precarious, which the arrival of more people can exacerbate. The challenge of the inward migration can also present 
opportunities for the in-migrants bringing skills and abilities to these new locations (Woods 2018). Planners will be challenged by the magnitude of potentially a million people displaced from the coast over the next 50 or so years (Hauer 2017). It is predicted that a majority of coastal Louisiana residents will migrate within the bounds of the state (Hauer 2017). Yet, the carrying capacity of some of the inland rural regions of the state is already stretched to collapse, racial tensions still exist, and fear of diminished quality of life likely make hospitality to receive more people difficult (Brown 2011; Derrida 2000; Kearney and Semonovitch 2011; Ogletree 2003).

The second part of the chapter suggests that both faith and culture can be utilized as assets for a comprehensive master plan that stresses innovation, collaboration, and inclusion of all regions of the state. Rejuvenation of neglected rural areas can take place through judicious work of boundary organizations ${ }^{1}$ and cross-boundary networks utilizing social and cultural assets (Hufford 1994). The rejuvenation of cultural arts and social assets, food, faith, music, stories, and family networks can retain and share historical knowledge to those who are leaving flooded areas, the sojourners, and those who are receiving the sojourners. Collaboration and relationship building can contribute to problem-solving and can be addressed through cultural networks (UNESCO 2018). The benefits of utilizing cultural assets within the restoration and rejuvenation of a people and place during and following social and physical disruptive events are increasingly being used by governments and institutions (CIRD 2018).

This discussion is focused on a rural to rural relationship of "historied" communities and "communities-of-place" who understand themselves as part of their surroundings and as responsible for the shared commons of their home, a sense of shared community that Tonnies famously called gemeinschaft (Tonnies 2001). Rural communities, in many cases, are self-organizing or managed and are built around shared lifeways and an ethical code of caring for and sharing with each other and their shared dwelling place (Low and Lawrence-Zuniga 2003). By exploring the ways faith, tradition, food, music, and storytelling intersect within rural areas of the state that have different religious and historical traditions, models of hospitality can be discovered and constructed. Through cross-boundary work and trust networks, the task can be the building of new community through co-learning (Maida 2007).

\section{2 "Wicked Problems" and Racial Divides}

The term "wicked problem" was coined by Horst Rittel to describe the challenges and complexities of problematization, the search for root causes and the necessary planning required for social issues that are out of the ordinary (Freire 1996; Fullilove 2004). Two defining characteristics of wicked problems that seem appropriate to

\footnotetext{
${ }^{1} \mathrm{~A}$ boundary organization is one that helps collaboration, information, and facilitation between diverse entities such as research disciplines, public policy, and community participants.
} 
Louisiana's current situation are the endless varieties of actions and approaches that could be taken, and the reality that any actions taken are likely to have irreversible consequences. If these actions generate more, new problems instead of addressing the existing ones, "wicked problems" will be exacerbated rather than mitigated. Because every action has an impact, best knowledge and principles have to be applied with each intervention, preferably in anticipation of the change (Rittel and Webber 1973).

The process of locating areas or regions in the state conducive for population growth is complex. Rural folks, for the most part, want to be with rural folks with similar shared social values.

When my people moved from Plaquemines to Amite all they wanted was a place to call home and a welcoming church and not to be afraid. ${ }^{2}$

The racial divides that have kept neighbors from knowing neighbors is still present in the state. Pushback from communities to resist "the other" happens all too frequently. In conversations with people in several of these locations, there is a sense of fear that permeates from stereotypes seen on the news and in entertainment. The Southern Poverty Law Center tracks changes in hate group behavior and has reported a rise in hate-related activity in Louisiana toward minority groups (SPLC 2018). ${ }^{3}$ Racial tensions can increase with additional people and diminished resources. Without a counter-narrative to highlight hospitality and creative interventions, there will be resistance to the in-migration. Following the 2016 flooding in New Roads, Louisiana, state recovery officials identified a predominately Black community that had flooded severely. They worked with the residents who wanted to move together to a less flood-prone area in a different section of town. The initiative experienced resistance from white residents who opposed their moving near them (Jones 2018). More recently, the community of Schriever was critical of the state's planning of the HUD-NDRC-IdJC Tribal ${ }^{4}$ grant, not wanting an open door policy of who could live in the Schriever community (DeSantis 2019). Another example occurring in the same area is the construction of slab-on-grade subdivisions in the Gray, Louisiana, area for residents moving from closer to the coast, with opponents claiming that the development is turning the quiet rural community into suburban "sprawl." Their argument is that the development is contributing to changing the density and identity of the receiving community and increasing the original residents' flooding.

A male resident whose family dates back to the original Acadian settlers stated:

My house and yard now flood with all the houses they stuck to the ground; they even took down the trees the kids played in. Those trees helped stop the water. It ain't right to do that to us. We can't even sit on the front porch...

\footnotetext{
${ }^{2}$ Personal communication with Rev. Tyronne Edwards, March 28, 2019. Deep appreciation is extended to Rev. Edwards and the other friends who offered stories, advice, editing, and critique to hone this chapter.

${ }^{3}$ https://www.splcenter.org/hate-map

${ }^{4}$ Housing and Urban Development-National Disaster Resilience Competition Award for Isle de Jean Charles Tribe.

${ }^{5}$ Personal communication with a Bayou Blue resident, April 22, 2018.
} 
Whether it is racial or economic fears or flooding from increased development, the outcomes are similar: Those who are at risk and need to relocate have fewer options to make informed choices of safe and healthy living places for their children because of the real and feared risks of the original residents.

The concerns expressed by rural communities about "newcomers" contain multiple issues. The landscape, the sounds, the way of life have forever changed and restructured the social networks of the historied families and the way their land was used for essential lifeways (Low and Lawrence-Zuniga 2003). One oft-voiced concern is the lack of protection of farms and forestlands that put rural lifeways, and all whom they serve with food, at risk. Common concerns heard from the Bayou Blue area are:

1. More flooding with the increased development (as quoted above)

2. More noise, less silence, quiet, and peace

3. More issues of road safety, not able to either walk or ride bikes

4. "Can't let the chickens run free" as farm life diminishes

5. Higher property taxes

6. Fear of crime and drugs as more people move into the area ${ }^{6}$

\subsection{Development Impacts on Rural Lifeway}

People moving in incremental steps trying to stay close to their former residence and extended family are attracted to the new development on former rural tracts of land. The demand for new housing is placing a demand on all available properties. Speculation of land by investors and realtors of larger parcels of rural/farmland property is occasionally causing friction between neighbors and in the families of commonly held land. Family members wanting to retain the land within their families can be in conflict with other family members who would like to sell for financial reasons. Because of increased land values, family members who would like to retain the land for family often do not have the financial means to "buy out" their extended family members. Conflict arises when the property sold becomes a convenience store, gas station, or development, contributing to a diminished rural lifestyle of the older homestead family next door. ${ }^{7}$

Rural areas in Louisiana are being gentrified by new housing developments that have changed the landscape and challenged the lifeways of rural families. "No place to park when gathering for crawfish boils at Mama's home" is not just an inconvenience. It is a significant change of family dynamics and community celebrations. Feeling left out of the conversation in preserving or negotiating their way of life has created harsh feelings not only toward the Parishes and the State but

\footnotetext{
${ }^{6}$ Self Development of People, Presbyterian Church (PCUSA), Bayou Blue correspondence/meeting, April 23, 2017.

${ }^{7}$ Self Development of People, Prebyterian Church (PCUSA), Bayou Blue correspondence/meeting, April 23, 2017.
} 
also toward the newcomer. For example, when a local farmer went to the Parish Council meeting to raise concerns of the amount of building and the cutting down of cypress trees causing additional flooding, he was told that the developer knew what he was doing and it was okay. There is now chronic flooding in the location of concern. $^{8}$

Some families who are being hemmed in or overwhelmed by the new developments and wanting to maintain their rural lifeways have encouraged their children and grandchildren to move to rural areas further inland and obtain land before it becomes too costly or is bought for new development. This process of moving from one rural spot to the next is not new. Over generations as the coast has slowly migrated inland, there has been a reconfiguration of fishing villages and small enclaves that meander up the bayou onto the next small village or town (Hemmerling 2017). Like many rural lifeway areas, in order to stay "rural," a bit of land is needed to grow food for an extended family and subdivide or share space for children as they grow up and live on the family enclave. In coastal Louisiana a tradition dating back to French colonial times, long narrow pieces of land measured by "arpents," were given to families so they could access the river or bayou as well as the woods and agricultural land.. In order to find space large enough to continue to engage in the giving of resources, food, and mutual aid, families now have to leapfrog over the towns and head further north and inland. As people move north, there are new sets of problems, many unexpected.

Louisiana families from coastal areas who headed inland following 16 years of disaster events from the time of Katrina believed they were making sound choices to avoid flooding. The people already living in the inland areas and the newcomers were not told that flood insurance was needed; thus, they assumed the area was safe. They had land and resources to share when their extended family needed a place to stay, grow crops, and raise animals. Some who purchased "safe" land found themselves flooded by the 2016 events. Believing they were moving to protect family and their future assets, they again were severely impacted by an "unexpected flooding event." Now separated from their original home base and again having their subsistence way of life taken by flooding, they are finding it more difficult to recover. The move inland brings with it other possible risks new residents will experience. One sojourner now returns to the bayou to sustain his inland family by helping others with shrimp, crab, and oyster harvesting. Others who have moved inland frequently return to maintain family connections, to participate in the life of the community, and to share food resources, such as taking sweet potatoes and kale to the bayou and taking shrimp back to the inland families. ${ }^{9}$

Many inland rural regions, as potential receiving regions, are coping with limited resources and bearing the burden of socially and economically constructed vulnerabilities with little attention to them, or public awareness from the more populated areas of the state. Information regarding the challenges to various parts of

\footnotetext{
${ }^{8}$ First Peoples' Conservation Council meeting notes March 162,018.

${ }^{9}$ Community conversations with Placquimines Parish residents December 2016.
} 
the state are not often part of public discourse and thus the needs are overlooked or not understood. There has been however, over the past several years, a growing public awareness as the online Lens and the New Orleans Advocate newspaper have highlighted failing infrastructures in the central and northern rural areas of the state such as the investigative reports on the condition of water systems (Ballard 2017; Wright 2019). The non-profit Together Louisiana ${ }^{10}$ has helped share and advocate as a voice with rural areas (Jones 2018).

The failing inland infrastructures have not been mitigated nor the risks of flooding conveyed adequately. The current flooding patterns caused by climate-change induced extreme weather may not follow historical patterns of events thus the local knowledge to predict and respond may be dimish. A Tallulah resident shared that her community was well aware of the infrastructure issues but lacked a voice or the resources to address them, so they "make do together" with what is on hand. ${ }^{11}$ Awareness of and attention to the risk conditions that exist in many rural areas, both on the coast and inland, have to be justly addressed. The carrying capacity of many parishes is at its limit, contending with bad water and overall failed health standards and flooding in their own right. These "layered" social, environmental, historical traumas and physical infrastructure deficiencies can be understood as a "wicked problem" (Laska et al. 2015). Environmental and social justice principles need to be applied in addressing the substandard conditions.

The displacement and transition of population, business, industry, and social functions from the coast is sometimes a hope to get to higher, drier, and safer places. Lasley has explored the organic self-transition of people from Saint Bernard to St. Tammany following Katrina utilizing social networks (Lasley 2012). As some parts of the community resettle to a particular locale, others in the social network including restaurants and businesses are drawn to the same area to continue old neighborhood patterns. As these new self-directed enclaves develop, such as in St. Tammany, they can either be stigmatized as outsiders or be socially merged into cultural fabric of the new location.

When one part of the population moves "up the bayou," it leaves a hole in the fabric of the community it left behind. Fewer people mean fewer relationship resources and declining population numbers threaten the doors of schools, churches, community buildings, and retail facilities (Lowlander Center 2017). Small businesses are stretched to doing "self-subsidizing" of their own businesses in order to serve their extended network of customers, family, and friends. ${ }^{12}$ Often a local void in services, goods, and community connections happens when a rural business closes placing extra hardships on the population remaining.

\footnotetext{
${ }^{10}$ Together Louisiana, www.togetherla.org

${ }^{11}$ Personal correspondence with Tallulah resident and church leader, March 2019.

${ }^{12}$ Group discussion with Appalachian College Students, bayou residents, and business owners, March 14, 2019.
} 


\subsection{Carrying Capacity of Coastal and Inland Communities}

In many rural areas of the state, be they inland or coastal, communities are experiencing sporadic or continual disruptions to the systems that impact their wellbeing. ${ }^{13}$ Coastal communities find themselves at the end of the road or bayou for services as the coast erodes their familial home and life-place. Inland communities are experiencing dysfunctional water systems and lack of social services with limited capacity to address the diminished services impacting their population (Ballard 2017; Wright 2019). For both the inland and coastal communities there are similar issues with dissimilar settings, inland and coastal, communities are reaching or are past their carrying capacity, and thus are approaching their tipping points (The Sustainable Scale Project 2003). The carrying capacity refers to the ability to maintain social, environmental, and physical infrastructure for a population.

Strangely, because of the magnitude of problems facing Louisiana, the state is at the forefront of problematizing the many risks and vulnerability issues, and thus has a critical leadership role to play in being visionary. The choice is dramatic and not overstated-the people, institutions, and communities of Louisiana can provide critical aspirational and visionary leadership by example or become a whole sacrificial state even beyond the coastal sacrificial zone (Freire 1996; Bowen 2009; Maldonado 2018).

- Resources for holistic problem-solving and planning in rural areas are not as prevalent as they are for small towns and urban regions, thus increasing rural areas' vulnerability (Cutter et al. 2016). As illustrated in Chap. 11 of this book by Alessandra Jerolleman, resources are not plentiful and capacity is lacking to apply and execute grant programs in rural areas. The lack of capacity is sometimes as basic as having no or limited access to Internet. Specialized rural organizations have taken the lead to assure rural areas are not left behind but their efforts are not always supported with equal political clout or voice to secure adequate proactive funding. Philanthropy is reluctant to fund rural programs especially if they do not see a strong outcome to their investments. One small family foundation shared that there is a stereotypical image of rural folks that tends to keep funders and resources away (Swierzewski 2007). Often these overlooked places will need long-term resources that support capacity building, staff support, and operational program funding. Lack of initial capacity or size should not be a factor in the allocation of funds.

With the state's loss of population in 2018 (Hauer 2017) and the anticipated future loss of population due to climate and economic patterns, needed revenue sources will be scarce. Rural and small communities already suffering from the downturn in the oil fields and agriculture industry will have to make cuts in services affecting the well-being of their immediate jurisdictions and the surrounding rural enclaves. The loss of revenue accompanying the loss of population will be intensified

\footnotetext{
${ }^{13}$ The interactions between human choice, physical infrastructure, and environmental stressors are key determinants for tipping points leading to systems collapse.
} 
with the next big hazard event, stretching recovery dollars and burdening the state further. Communities of color will be the most impacted in rural areas where political agency is ignored (Doherty 2004).

Additionally, changes in environmental conditions will impact all varieties of wildlife and their movements and habitats. Human and non-human habitat adaption to weather and climate stressors will become increasingly challenging to traditional agricultural practices and ecological preservation. The "community" that is in transition includes all the wildlife and plants. Planning for transition is for the entire population, human and non-human. Hunters and fishers, a large economic recreational industry, are paying close attention to these changes and are often advocates in preservation practices. Decision-making processes become networks or a web of life that is complex (Morton 2017). In short, how the lifeworld and natural resources are hosted and carefully managed in the "retreat" from the coast will have a direct impact on all species native to the entire area.

\subsubsection{Health as Indicator}

The Robert Wood Johnson Foundation health report gives Louisiana a low score on overall wellness and well-being. The map (Fig. 7.1) highlights the severity of health conditions in Louisiana (University of Wisconsin Population Health Institute 2018). The conditions for determining the health score include individual choices in health behavior such as exercise, tobacco, diet, drug use, and social and economic factors such as access to limited quality care, education, employment, social support, community safety, and income and the physical environment attributes that include air and water quality, housing, and transit (University of Wisconsin Population Health Institute 2018). Inadequate housing, weatherization, and inability to maintain and repair housing contribute to vulnerability (Tierney 2014). Mitigation for deteriorating housing stock is challenged by lack of rural funding (Horney et al. 2017). Physical health indicators reveal that the state ranks toward the bottom of all states in many functions critical for a vital population (Horney et al. 2017).

Indeed, Concordia Parish, north of Baton Rouge on the border of Mississippi, has been singled out as having the worst health conditions in the country (Belluz 2016). The Parish is lacking in many of the essentials including access to clean water, sanitation, affordable healthy foods, and safe housing (Doherty 2004). Other inland communities south along an 85-mile stretch on the Mississippi River between Baton Rouge and New Orleans, often referred to as "Cancer Alley" (Bullard 1994; Blackwell et al. 2017), are surrounded by 25 percent of the nation's petrochemical production (Jackson and Chapple 2018). The map (Fig. 7.1) shows toxic release and superfund sites that have a bearing on health factors of the surrounding communities (Bullard 1994). Communities of color and those of lesser means are the ones who suffer most with the contamination in many places causing abnormally high cancer rates, asthma, miscarriages, and other health-related issues (Bullard 1994). Jonathan 


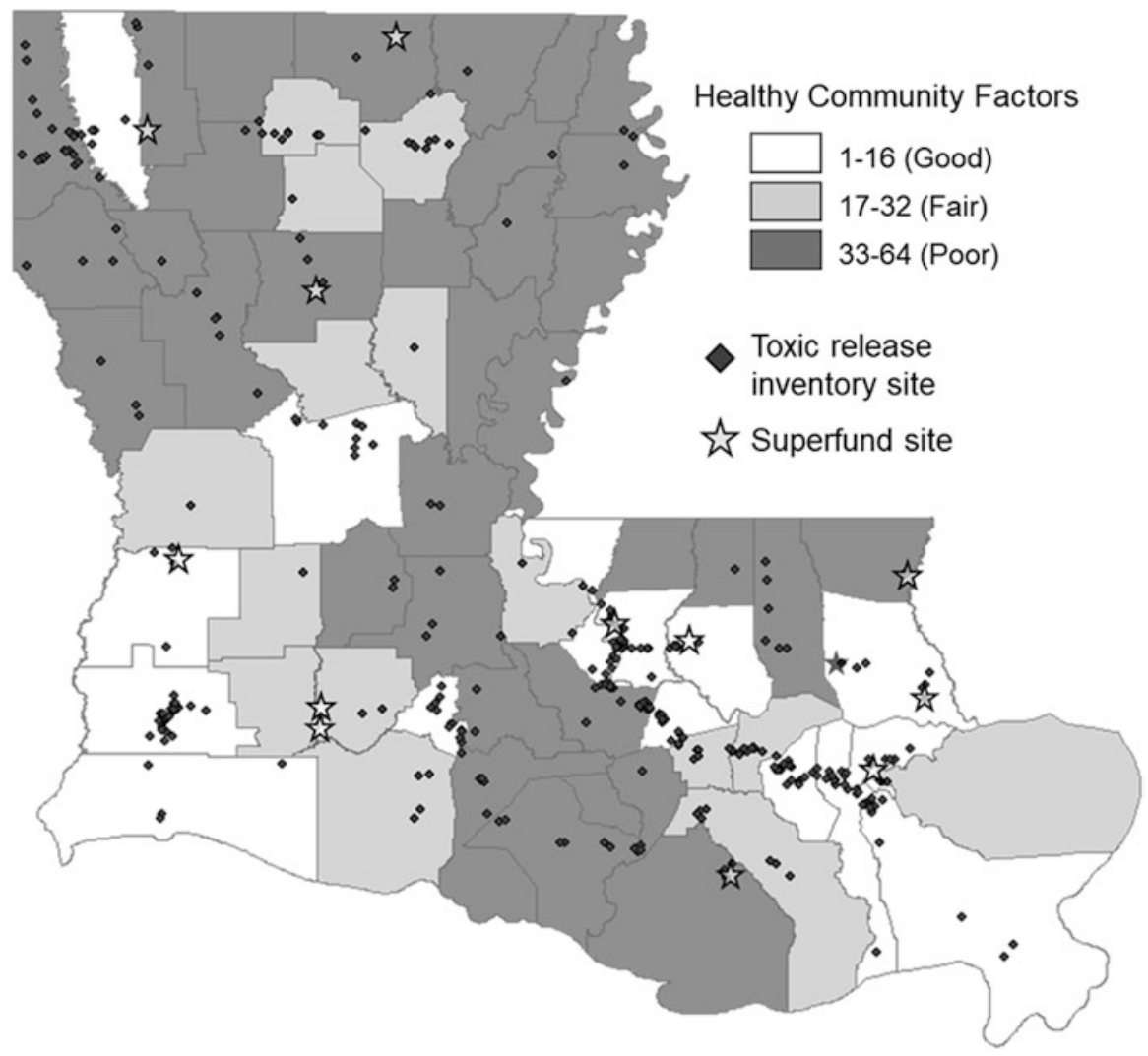

Fig. 7.1 Map showing health factors rankings by parish and locations of toxic release inventory and superfund sites in Louisiana. The ranks are based on four types of measures: health behaviors, clinical care, and social and economic and physical environment factors. (Data retrieved from County Health Rankings \& Roadmaps and the Environmental Protection Agency (EPA))

West, a UNO student, described being weary from the grief of having seen cancer in every one of his friends' families in Norco, LA. ${ }^{14}$

\subsubsection{Water Quality}

The conditions that make for either a vulnerable or a sustainable population include the capacity of different communities to address the long-term and chronic everyday disasters they face (Bolin and Bolton 1986). Families need safe water to drink, cook, and bathe with. Purchasing water is not an option for people living in areas with high unemployment and underemployment. People want to be generous but it

\footnotetext{
${ }^{14}$ Personal communications at University of New Orleans, May 18, 2006.
} 
is difficult with limited resources. Ms. Ancar, a resident of Grand Bayou, Louisiana, often said to visitors “Come join me for some coffee and if I don't have coffee we will have water" (personal communication April 9, 2003). For inland communities desiring to give hospitality, some residents have no water to share.

The quality of water is threatening the health of the most vulnerable, elderly and children, sick. The physical infrastructures vital for water delivery in the central part of the state are close to collapse (Ballard 2017). In 2013, the American Society of Civil Engineers gave Louisiana an infrastructure grade of "C," after finding that 62 percent of the state's roads were of mediocre to poor condition, 3815 bridges were structurally deficient or functionally obsolete, 33 dams were considered "high hazard," and drinking water and wastewater systems were in need of $\$ 10.9$ billion in improvements during the next 20 years. Many of these drinking water and wastewater systems are located in rural areas (Schliefstein 2013). The combined conditions of inadequate storm water drainage, potable water, and sewage, accompanying nuisance flooding, will soon make coastal communities uninhabitable (Ruppert 2019).

"I turn on the tap and the water is sludge," a Tallulah resident shared with the author. "I had to move my mama since that is all she had to drink." ${ }^{15}$

Safe clean water is clearly essential to basic health standards (Steingraber 1998), yet water required for daily use may be one of the state's biggest challenges (Adeniyi et al. 2016). The now-closed England Air Force Base in Alexandria, Louisiana, is an EPA superfund site that has the highest detected deadly PFAS ${ }^{16}$ levels in groundwater of any PFAS contamination site in the nation. Water from the site has 10,970,000 parts per trillion (ppt), 1 million times more than the risk level determined by Harvard public health and that the Agency for Toxic Substance Disease Registry (ATSDR) recommends as safe (Reed 2018). The Environmental Working Group (EWG) report on drinking water by zip codes showed that potable water in all of the Parishes in Louisiana contained either carcinogenic chemicals or metals. Despite the EWG report of carcinogenic and other contaminants in potable water, the water districts are still in compliance with legally mandated federal standards (EWG 2015). The map (Fig. 7.2) delineates cities and development, 2018 coastal predicted flooding moderate risk scenario with no action, rural farmland under cultivation, open territories either forested, or held by government entities and in gray, the water infrastructures in immediate need of repair.

My baby said his eyes were burning when he brushed his teeth. I told him to turn off the water. Your eyes shouldn't burn from the tap water when brushing your teeth!.. ${ }^{17}$

This and the previous quote come from communities in distant parts of the state from locations that will have to relocate or receive families. Water quality in the state for many people is a present concern for their health and an economic hardship in obtaining alternative safe water for drinking, food preparation, and personal hygiene.

\footnotetext{
${ }^{15}$ Personal communication with Tallulah resident, March 16, 2019.

${ }^{16}$ Perfluoroalkyl substances www.health.re.gov/water/about/pfas

${ }^{17}$ Personal communication with Chief Shirell Dardar at Knights of Columbus Hall, March 14, 2019.
} 


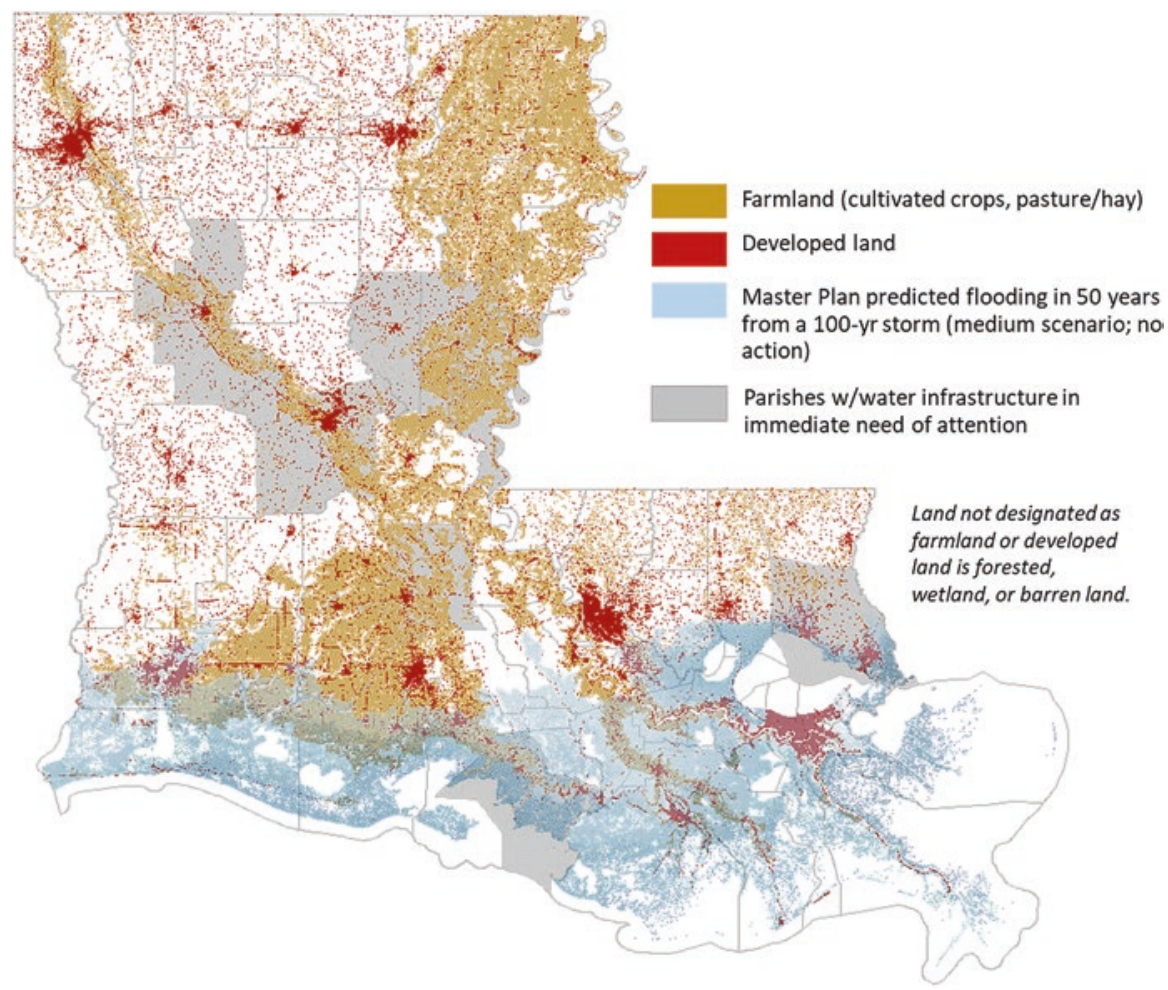

Fig. 7.2 Map showing where select land cover categories in Louisiana overlap with dysfunctional water infrastructure and which areas would be at risk of flooding in the near future. (Data retrieved from National Land Cover Database (NLCD) 2011 edition; Rural Water Infrastructure Committee (2018), \& Coastal Protection \& Restoration Authority CIMS application)

\subsubsection{Resilience and Tipping Points}

How do you know when you reached a tipping point, only when you passed it (Ann Claire Phillips, Rear Admiral, USN (Ret.) October 2017).

Resilience is the ability of a system to absorb shocks and adapt. In ecological terms, when the stressors have reached the tipping point, the system enters into a new regime (Walker and Salt 2012). Some rural areas within the state have surpassed their ability to absorb additional shocks. It is similar for rural communities that have endured chronic and sudden social impacts where a tipping point happens and the rural community either dissolves or has to reinvent itself through creative and radical actions (Nored 1999; Akuno et al. 2017). Examples of such radical holistic remakes come from Kali Akuno's work in Jackson, MS, and the work of Rev. Nored in a rural enclave outside of Birmingham, AL. In order for high-risk areas of the state to avoid becoming a "sacrificial zone," radical hospitable plans of rejuvenation must become priority activities (Maldonado 2018). 


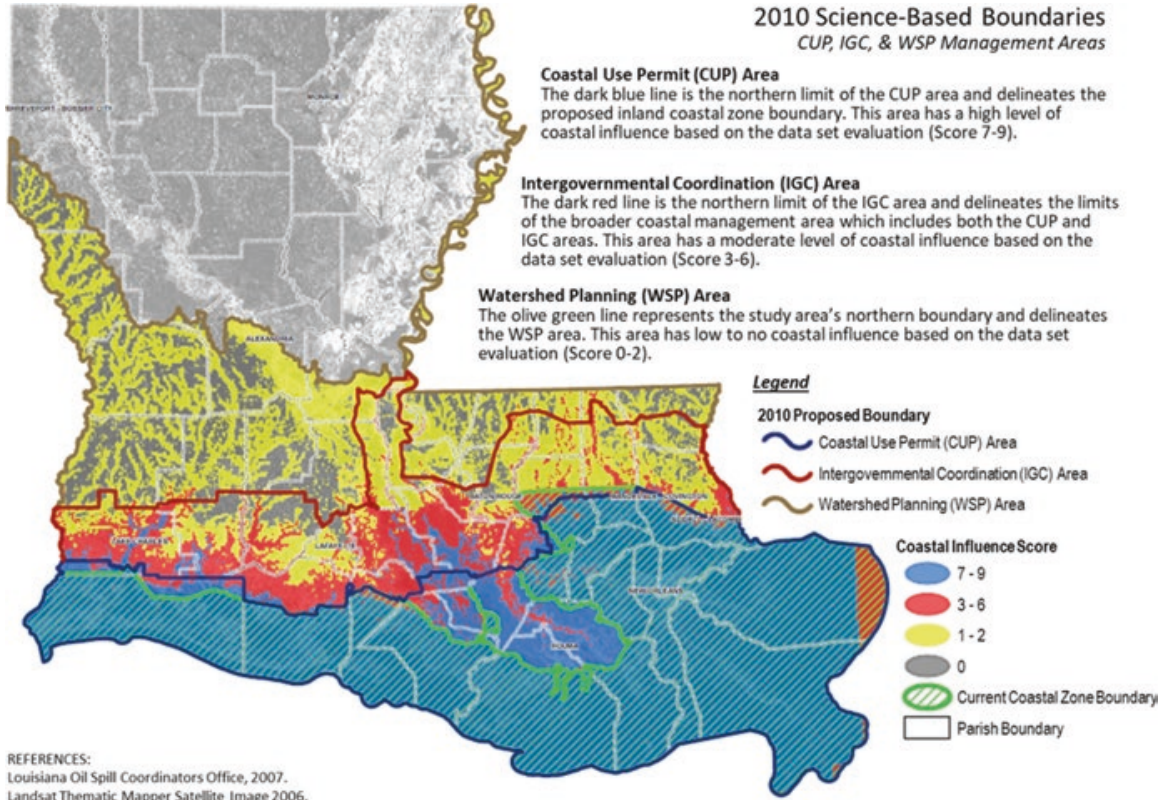

Fig. 7.3 Map showing updated definitions of Louisiana's coastal zone. (Image source: Louisiana Department of Natural Resources, Office of Coastal Management)

Moving from rural place to rural place is difficult and made more complicated by the unknowns of risks and climate. This map (Fig. 7.3) shows the delineation of water management areas. Each area will have different regulations in accordance with federal agencies and with them the availability of agency resources. The rate of acceleration, which the coast is moving inland, has been increasing faster than predicted and will probably continue to do so in the near future (Goodell 2017). As seen in the maps portrayed in Figs. 7.1 and 7.2, most of Louisiana is rural. The serenity and beauty of the rural areas have provided forest products, potatoes, peanuts, cotton, poultry and poultry products, soybeans, strawberries, and sugarcane. It would seem that finding high ground and open area would be easy enough when considering locations for sojourning populations. But it is not so simple to find a good safe place, as seen in the first two maps that indicate land loss, health concerns, and crumbling infrastructures (Curth 2018). The first two maps show existing stressors to health and safety, while the third map shows the new coastal management changes that will require different permitting within the zones. With the inclusion of more inland areas within the coastal permitting area, it too will add time and burden for the extra expense of permitting. Given the gravity of challenges to all regions of the state, it begs the question of how and where to start. 


\subsection{Desperate Times Call for Creative Measures}

The development of comprehensive inclusive statewide frameworks and working models is required to address the problems. Contemporary planner and political philosopher Iris Young (1990) argues that the paradigm of "development justice" is through people's capacities for free and autonomous decision-making in inclusive democratic engagement and processes (Harvey 1996): Ideally, the inclusion of the entire community with all of its social differences together must have a voice in the problematization and planning process even if the community members/families do not move together as a community. The community, especially those with local and traditional knowledge, can give voice and representation to the non-human inhabitants that will also be migrating. The trajectory Young is suggesting is in alignment with the work of planners over the past 100 years such as Benjamin Marsh, Arturo Escobar, and Dennis Goulet who have all posited that planning has to be for the benefit of the people and the health of the whole community, human and non-human (Marsh 1909; Escobar 2008; Goulet 1995).

To democratize the process and the work of planning, the ones most impacted by the decision-making, the vulnerability-bearers must be included (Krajeski 2018). By involving those who are most likely to bear the consequences of extreme events, the visioning of the future can be inclusive and the quality of the planning will benefit from a variety of knowledge, backgrounds, and experiences. The inclusion of vulnerability-bearers in problematization and problem-solving often leads to creative alternatives and healthier outcomes as well as a broader base of support for the project. The "down the road" game plan for possible relocation teeters between the imagined scenarios that will be possible and the triggered event. Each formal or informal planning process, given the limits of people's time and the resources of a community, must solve the most critical issues impacting people as defined by the community of vulnerability (West et al. 2008).

Wisner et al. (2004) posit that the disaster following on a hazard event is directly related to the amount of socially constructed vulnerability, the capacity of the jurisdiction, and the extent of mitigation ("adaptation" in the climate change vocabulary). The disaster that follows a hazard event can be minimal or extensive depending on these three variables, all of which can be addressed through human interventions that include enhancing the capacity of a community and eliminating historical and socially constructed vulnerabilities. These types of interventions for a healthy community are not enough unless they infuse adaptation into the physical and social fabric of the communities (Highfield et al. 2014). Without the interventions, both the sojourner and the receiving community will have increased risk and diminished social health conditions. 


\subsection{Counter-Narrative Frameworks and Problem-Solving Approaches}

This section of the chapter will suggest counter-narrative frameworks from historical models that achieved innovation in spite of grave challenges (Scott 1990). It will also explore current problem-solving approaches that place citizen engagement at the core of a local and larger state model. By utilizing core strengths and assets of each region of the state and by collaborative and cross-boundary networks, the work can start building relationships with the already existing networks of family, faith, food, and music groups within the state (Malsale et al. 2018). Starting with what Friere calls problematization-finding root causes and doing critical thinking of problems - collaboration by kindred groups and communities-of-interest can build alternative futures through co-creation of knowledges (Freire 1996; Foucault 2009). Problematization helps understand the underside of wicked problems, as they are symptoms of other problems (Rittel and Webber 1973).

Addressing population relocation through shared cultural experiences opens conversations in a "safe place" that builds relationships (Woods 2018). In this visioning process, as conversations about transitions of populations are happening within the faith community, similar discussions are taking place in government (top down) and non-profit agencies (grasstops), but not necessarily taking place between and with community members at the grassroots. There will be many sojourners within the state, and there will be many who will receive the stranger. It should be a slow, long, and intentional process through which trust and relationships will be forged. And modeling of successful efforts is shared among communities. By building relationships of trust first, with and between the populations that are most impacted, difficult issues and topics can be broached with openness for problemsolving (Park et al. 1993). Giving attention and support first to the vulnerabilitybearers is necessary for building capacity and for the community's engagement with those who can provide support, for example, faith communities, universities, agencies, or non-profits (Krajeski 2018). Vulnerability-bearers will be both in the moving and in the receiving populations.

Building on community connections and strengths alone will not be sufficient to rectify the complex issues that have caused and maintained the wicked problems outlined in the beginning of the chapter. A robust master plan for the state is desperately needed that takes on the qualities of a New Marshall Plan, understood like the WWII Marshall Plan, as an effort to rebuild infrastructure lost, remove contamination, and rekindle a safe economy and agriculture. Louisiana's current plight needs nothing less than such a robust plan. A New Marshall Plan can embrace asset-based planning with imagination to harness every possible resource available within the receiving regions from the cultural strengths and inclusive of the faith, $\mathrm{NGO}$, and business and governmental communities. It could counter the lack of carrying capacity of the state with a new ethic of a caring capacity. The key is complex integrated thinking and resourcing (Thomas 2014). The plan would be a large-scale model for the state, much like what Bob Becker, CEO of New Orleans 
City Park, used for post-Katrina recovery and redevelopment of one of the largest parks in the country: have a vision, get it into workable components that augment each other, and attract resource providers to complete those outlined components as through interest in supporting the plan develops and grows (Pope 2013). The vision itself draws resources; it must be innovative with a strong commitment to a caring capacity, one that rejuvenates and restores community with community.

And, because Louisiana is "ahead of the curve" in needing such a large-scale plan, that the state is an innovator on this New Plan, it will attract donors.

If they are done well, innovations in society have the capacity to gather a following because they are visionary, they can give hope, they can be just, and they offer a way for people to be involved (Rogers 2003). The innovations also often have the quality of large thinking even though their implementation begins small. The innovation as experienced in intentional planned communities offered needed hope and justice in difficult times of segregation, housing needs, economic exploitation, and challenged agricultural land use (Howard 1965). Models are shared from the faith community in the following section. They were and are models that defied the impossible. They can give hope and understanding for the tremendously large task ahead for Louisiana.

\subsubsection{Faith-Inspired Models for Change}

People in Louisiana continue to have strong faith connections, tied with Alabama, with the highest percentage of people in the USA who are linked to faith organizations (Cooperman 2015). The map on religious preference from the 2010 US Religious Census data shows a clear distinction of faith preferences in Louisiana (Fig. 7.4). Roman Catholic and Southern Baptist are the two dominant faith groups, followed by the United Methodist Church (ASARB 2012).

A sharp geographic dividing line between Catholic and Baptists is based on historical migration patterns. Historical colonial dominance of the coastal area by

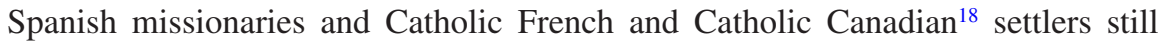
influences the southern coastal region. The northern region was influenced by Protestant itinerate preachers and missionaries and settlers from the central and east coast once Louisiana became a state and has been designated by many as part of the Bible Belt (Tweedlie 1978; Zelinsky 1972). As populations shift, so will the religious mix in the central and northern parts of the state. Catholic and protestant congregations will need to find ways to carry their traditions as they find places to establish congregations, schools, and other faith-based facilities in new areas. They will be sojourners in a new land and will look for hospitality in the place they reside and their faith practiced. Both the sojourner and those extending hospitality will

\footnotetext{
${ }^{18}$ The predominance of French rule and the Catholic Church manifest themselves into the currentday Napoleonic Law still practiced throughout the state and the county units of government, called parishes.
} 


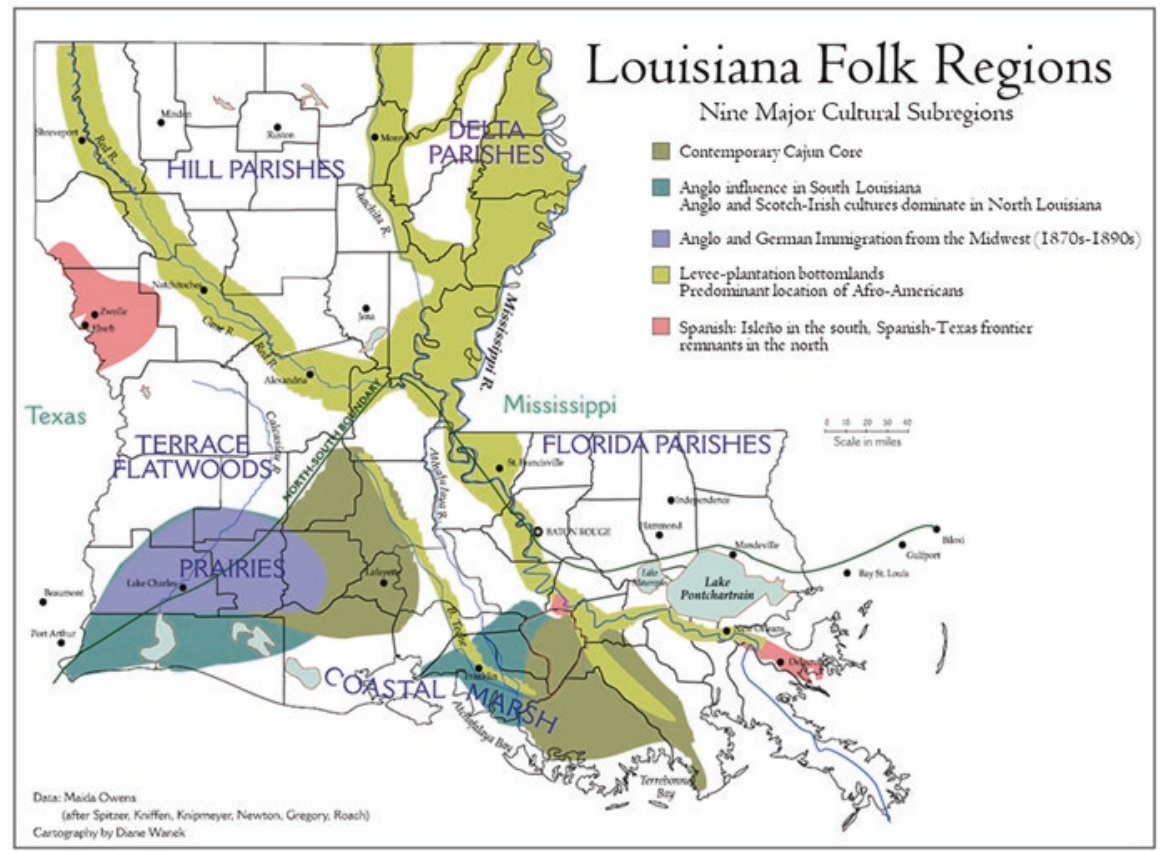

Fig. 7.4 Map showing Louisiana's main folk regions and nine cultural subregions. (Image source: www.louisianafolklife.org)

find a rich tapestry of history intertwined with traditions of music, stories, and outreach ministries of service that can benefit the new communities.

Protocols of faith practice are different between Protestants and Catholics including the judicatory structures and modes of worship such as liturgy and the adherence to Holy Days. Denominational leadership will be essential in helping to create a welcoming situation for all faiths. Ecumenical organizations like the Louisiana Interchurch Conference and Church Women United can be instrumental in finding common ground through shared faith values and faith stories.

Over the years, faith-based initiatives and faith-based work have birthed innovation during times of distress and turbulence offering hope and alternatives. These initiatives include leaders such as Rev. Abraham Lincoln Davis, founder of Southern Christian Leadership Conference. ${ }^{19}$ Others also helped usher in new ways of being within community. Not waiting for government to take action, the faith community has often taken the lead to advocate and/or provide education, health, housing, and environmental witness and social justice in general. ${ }^{20}$

\footnotetext{
${ }^{19} \mathrm{https}$ ://kinginstitute.stanford.edu/encyclopedia/southern-christian-leadership-conference-sclc, Rev. Davis from Bayou Goula was the first Vice President of SCLC.

${ }^{20}$ National Council of Churches: www.nationalcouncilofchurches.us
} 
The following are some illustrations of faith-based initiatives that can be helpful to the work on leaving and receiving communities.

- Koinonia Farms in Plains, Georgia, started as a racially integrated community land trust in 1942. It was the utopian dream of Clarence Jordan, a farmer and Baptist preacher, devised to promote sustainable agriculture and animal husbandry. It helped poor rural residents move away from cotton, the crop equated with slavery, and have a healthy life. The ecologically diverse farm experimented in various forms of affordable housing and water system techniques (Jordan 1972).

- Through Millard Fuller's experience at the cooperative, he founded Habitat for Humanity. The experiment outlasted the cross burning and threats on others connected to a radical idea of social and economic justice. Jimmy Carter, a neighbor, was inspired by the achievements of Koinonia.

- While Jordan was addressing economic and racial justice at Koinonia, Dan West was developing what has come to be known as the Heifer Project International. It started with a simple idea to send cows to Europe, restoring farms that had been destroyed during World War II. Through partnerships with US government agencies, a steady supply of animals of all varieties was provided to European farmers. The first born of every animal was gifted to another farmer, leading to a slow but continual recovery (Kettering 2003). Following Katrina, the Heifer Project helped restore the fishing fleet at Grand Bayou, an indigenous community in Lower Plaquemines Parish, and extend crop resources to Afro-American farmers in the north central part of Louisiana.

- Likewise, Serrv, another innovation of the era, still flourishes today. It addressed the postwar economy of local families in Western Europe to help displaced refugees trade their handcrafts for income. Today, fair trade has become a norm. Serrv is a founding member of the World Fair Trade Organization and the Fair Trade Federation and employs 8000 artisans and farmers in 24 countries. Both ideas were visionary for the time (Serrv n.d.)

- Grand Bayou Native Village located in Plaquemines Parish initiated a Participatory Action Research project in 2002 following Hurricanes Lili and Isadore through the support of Church World Service and PCUSA. After establishing their vision of "saving their culture and land," the project partnered with many experts from various disciplines and backgrounds, being awarded a National Science Foundation Grant to do the cross-boundary work necessary to rebuild their village and establish and enhance their political and cultural voice. It was heralded by the then disaster program director of NSF, a cutting edge success (Peterson 2011).

Each of the above programs were not only innovative but they also responded to an immediate human crisis with effective problem-solving. Each program also created a network of collaborators that helped support the vision that is necessary to have long-term sustainability. Following in the tradition of dialogue, the Louisiana Interchurch Conference (LIC) is in an excellent position to help bridge geographic and religious boundaries. Its board of directors spans the state, representing 
leadership of both Catholic and Protestant traditions. LIC can and has been a boundary and facilitating organization addressing issues pertinent to most Louisiana residents, such as housing, farms, children's welfare, disasters, and the environment. Many of the faith leaders involved with LIC are involved with ecumenical and interfaith projects that contribute to the well-being of the state and become a link between stakeholders to address issues. For example, Rob Gorman from Terrebonne Parish, previous chair of the LIC Environmental Taskforce, helped in the creation of the Coastal Coalition and has been a coastal leader for many years.

A recent sign of hope of a faith-based initiative in Louisiana is the work of Mary Queen of Viet Nam Church. Following Hurricane Katrina, Mary Queen of Vietnam Catholic Church (MQVN) under the leadership of Fathers Vien Nguyen and Luke Dung $^{21}$ became the hub for recovery of the New Orleans East area. The efforts of the congregation resulted in the development of a master plan for the immediate community that includes community gardens, economic endeavors, elder housing, a Community Development Corporation (CDC), and health services. ${ }^{22}$ Youth and elderly were a critical part of the recovery and of the continuing work of New Orleans East.

\section{Faith Influenced Land Trusts to Address Social and Environmental Justice}

Inspired by Dorothy Day and the Catholic Worker Movement (Coles 1987) that promoted equality and justice, Chuck Matthei envisioned farm settlements and land trusts as an innovative tool that can be used to address distressed rural communities (Matthei 1992). Community and conservation land trusts can be used in creative ways to heal environmentally distressed sites and act as protection against gentrification for traditional and historied communities. While community land trusts are primarily focused on human community, the conservation land trust focuses on the non-human environmental setting. Both types of trusts are necessary, one to protect land from gentrification and the other to provide necessary buffer and healing for green space. In Louisiana, one possibility is to have conservation trusts that buffer areas that have been heavily contaminated over the years from oil, gas, and farming practices. The conservation trusts can help in the rejuvenation from the impacts caused by the by-products of those practices. Conservation trusts can help restore healthy water systems, air, and habitat for outdoor activity that is loved throughout the state (Davis 2010).

Community land trusts provide protection from gentrification for communities that are rejuvenating themselves. ${ }^{23}$ Creative uses of community land trusts have been utilized in communities of color to preserve and protect community, cultural and heritage, that sometimes gets disrupted by various development strategies such as economic renewal projects. The Albany, Georgia, land trust is an excellent

\footnotetext{
${ }^{21}$ https://www.npr.org/2011/08/29/140036221/turning-toward-faith-during-hurricane-aftermath

${ }^{22}$ Mary Queen of Viet Nam Community Development Corporation, mqvncdc.org

${ }^{23}$ See, for example, New Orleans' Central City Community Land Trust that serves that exact purpose: https://www.ccclt.org/how-we-work/
} 
example of an established community that has weathered time and endured racial injustice (Davis 2010). Louisiana could create a trust to take on an innovation of "climate land trust," land held for restoration and renewal until it is needed by a transitional community or transitional families for resettlement. The innovation of such a land trust can lend itself to the regeneration of damaged land and water helping to address the wicked problems mentioned earlier in this chapter.

\subsection{Folk Traditions as Rallying Points}

Louisiana's population reflects the state's historically diverse economy. Being on the Mississippi River and having a major port on the Gulf, the access to the state resulted in various diversities. The state's connection with sugar in the Caribbean and bananas and coffee from Central America gave variety to music and foods. The horrific years of the slave market centered in New Orleans brought knowledge and rich traditions from Africa. The multiple derivatives of places of French-speaking people brought traditions and foods from around the world. Figure 7.5 shows the cultural distribution of people who carried their traditions that helped create the diversity of festivals, food, faith, and music.

The map illustrates the predominance of Euro-American and Afro-American population in the central and northern regions of the state while the southern region has a greater ethnic diversity. Notice that the historied Cajun and German enclaves are not well represented in the northern regions of the state (Brasseaux et al. 2005). There are many cultural groups that are not indicated on this map such as the significant Vietnamese population in New Orleans and southeast delta region. The map does not reflect the 79 self-identified indigenous tribes within the state. It is not an exhaustive representation but gives an indication of the larger ethnic populations.

\subsubsection{Power of Cultural Festivals}

The state of Louisiana is one of the most popular tourist destinations in the country. Contrary to the low ratings on social health factors, the state excels in offering food, hospitality, happiness, music, and faith (Newport 2017; Cooperman 2015; Morton and Lagrave 2018). The people and communities of the state offer a celebratory culture that is sought by visitors and relished by its residents. With over 520 festivals listed within the state in 2018, there were themes that helped build knowledge while highlighting the strengths of the state's cultural diversity.

Louisiana Office of Tourism's "Feed Your Soul"24 advertising campaign highlights the joys of multiculturalism, food, festivals, and music. The listings of monthly activities throughout the state are evidence of the wealth of cultural talent

\footnotetext{
${ }^{24}$ www.Louisianatourism.com
} 


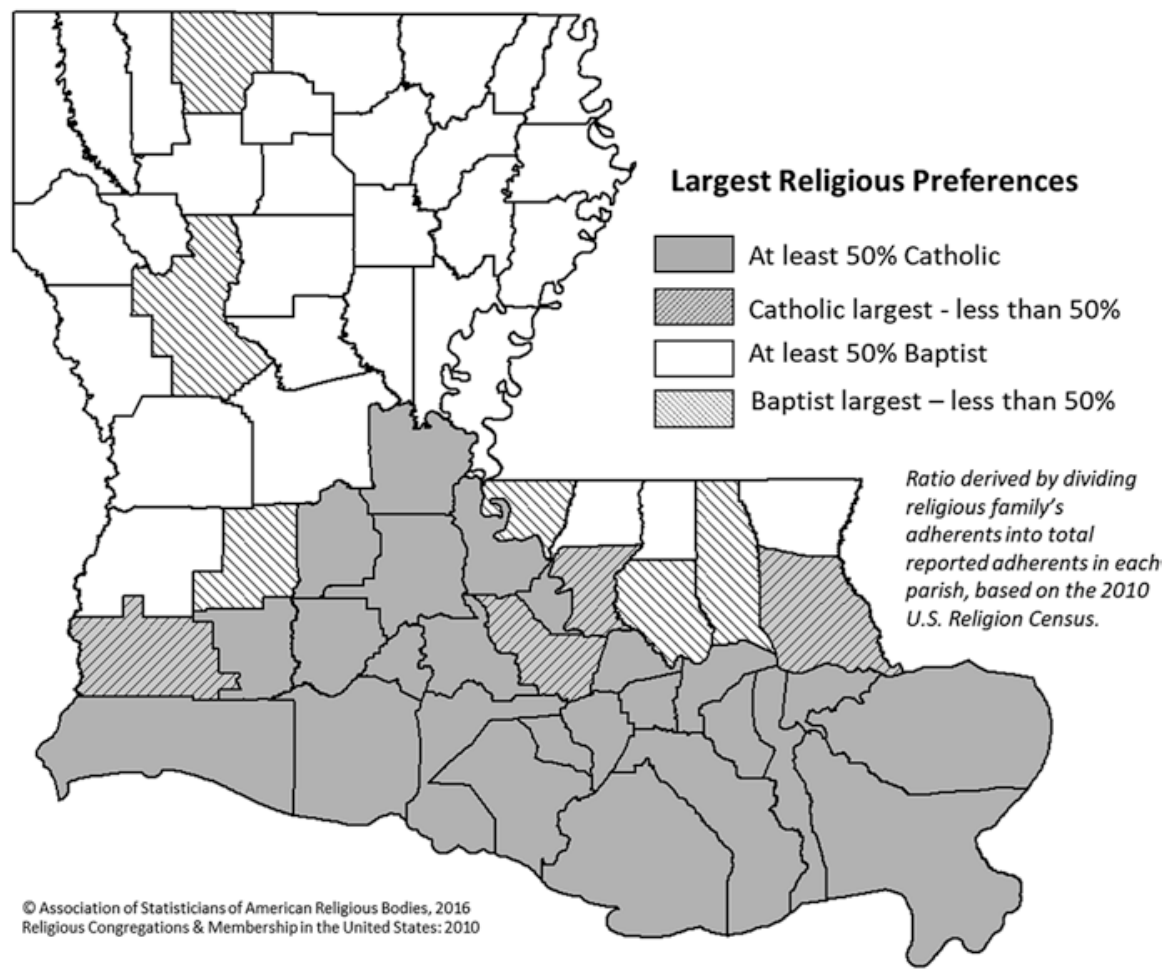

Fig. 7.5 Map showing the prevalence of Catholicism and Baptism by parish in Louisiana. (Adapted from 2016 U.S. Religion Census: Religious Conregations \& Membership Study (Association of Religion Data Archives 2016)

and ingenuity garnered by local and regional groups. Utilizing the natural convergence of food, music, festivals, and faith at work in the state organically builds relationships and trust.

The festivals are testimony to the capacity, imagination, and hard work of the communities. The organizational coordination and resources that are expended to host the festivals often take a year of work. Krewes for Mardi Gras coordinate and raise their own funds, the wooden tinder bonfire structures along the Mississippi River in Lutcher for Christmas Eve beacons to St. Nick take months to build and are works of art. ${ }^{25}$ Even a local congregation's fundraiser for a cancer patient can take immense work and coordination. Self-organization is a skill and asset seen in the festivals and community celebrations. The altruism that Ostrom (Ostrom and Walker 2003) speaks of within communities is witnessed in these festival events. Grassroots mobilization and altruism can be quick and swift when there is a disaster as seen in groups like the Cajun Navy. Grassroots ability and capacity are present in the state, often in informal networks.

\footnotetext{
${ }^{25}$ Christmas Eve Bonfires: www.festivalofthebonfires.org
} 
Although there is capacity to mobilize within the state, there are other interpersonal dynamics that will restrict successful relocation such as racial challenges, regional biases, and prejudice. Recently in April 2019, three Afro-American Churches in St. Landry Parish northwest of Baton Rouge were burned as hate crimes. These issues cannot be ignored, including when relocation is being considered. Addressing them must be part of the needed reconciliation and healing as changing inland communities reconfigure themselves.

Prejudice is real and experienced in the daily lives of people throughout the state but can be confronted and addressed through shared cultural connections. Through the work of youth and local congregations, for example, proms in northern parish high schools have moved beyond outdated codes of segregation as recently as 10 years ago and are now integrated.$^{26}$ Another example is found in Arizona. Tucson Meet Yourself was created to showcase the many cultures and faiths residing in Tucson. The event began for cultural awareness, understanding, and dialogue that can overcome prejudice. Louisiana Folklore Society has initiated a project called Bayou Culture: Moving Traditions Forward ${ }^{27}$ to help support the bayou region to discuss what traditions communities want to take with them as they move. The discussions have brought a diverse working group together to identify core cultural values people want to save. ${ }^{28}$ Events that bring a mixture of backgrounds together help people become less apprehensive of other cultures, customs, and practices and lay a strong foundation for trust. ${ }^{29}$

\subsection{Cross-Boundary Work: Trust and Relationship Building}

Elinor Ostrom, Nobel Laureate, examined the concept of trust and conducted extensive research on the topic to determine if people were apt to be trusting, especially in a relationship of reciprocity and mutual caring. Her work was explored across geographic and cultural boundaries and found that the more understanding people had of each other, the greater the levels of trust. The research showed that generosity and good will were extended even at a minimal level of interpersonal knowledge (Ostrom and Walker 2003). Her interest in mutual support was fundamental to her understanding of the "commons" and how we can restore a society and economy to be equitable and just. This understanding of "commons" is seen in the mutual aid and stability of the population within the rural areas of the state and in its communities' self-care, generosity, and hospitality (Peterson \& Krajeski 2011). Many folks in the bayou region refer to their community as a "giving" lifeway based on a web of life that is both sacred and joyous and full of awe. It is situated or place-based

\footnotetext{
${ }^{26}$ Jonathan Coats, May 1, 2008, Outdated separation ends with integrated high school prom. www. NOLA.com

${ }^{27}$ Louisiana Folklore Society, www.louisianafolklore.org

${ }^{28}$ www.Tucsonmeetyourself.org

${ }^{29}$ Louisiana Folklore Society, www.louisianafolklore.org
} 
knowledge, as in "the shrimp are giving" and "we are giving to family" (Regis 2019). The experienced knowledge of the rural communities supports the concepts of Peter Park, and the development of relational knowledge to build networks and collaboration for problem-solving, as well as Ostrom's concepts of altruism (Park et al. 1993).

Projects that emphasize the co-creating of place, knowledge, and a healthy future can and will build trusting relationships between the displaced and the receiving community (Hillier and Rookby 2005). As trust is gained and projects honed, resources to bring them to fruition can be secured through the efforts of a collaborative team. Especially for small rural communities, teaming small communities together gives more clout or voice in the securing of resources. It serves to maximize human resources as well as people are often overtaxed and wearing many hats.

In Louisiana in the early twentieth century, an innovation brought together best practices held by government agencies at the time to create the Terrebonne Project, a planned community in Terrebonne Parish (Conn 2009). It was one of the hundred communities created all over the country, including Alaska, planned by the Federal Resettlement Administration. It addressed the massive displacement of tenant farmers and small business owners as a result of the Great Depression, the great flood of 1927, and the Dust Bowl. Using ideals set by Sir Ebenezer Howard's "garden city" movement, Rexford Tugwell used all available resources in President Franklin Delano Roosevelt's Cabinet, from agricultural, health, arts and folk life, housing, and industry to create resettlements for displaced families (Lash 1988). Using best knowledge of sustainability from around the world, new communities were birthed and families were given the means of sustainability with a small farmstead and involvement in a larger community enterprise.

The formal Resettlement Administration was short lived due to the need of resources for the impending war. However, in spite of the lack of continued funding and support, many of the communities survived by the participants' initiative to make the planned community work (Holley 1940). The popularity of healthy planned greenbelt communities of the New Deal continued to grow, as seen in the work of James Rouse in places like Columbia; Greenbelt, Maryland; and Green Hills, Ohio (Chappelle et al. 1986).

Cross-boundary organizing can help facilitate linking programs like Louisiana Watershed Initiative ${ }^{30}$ and EPA's Sustainable Healthy Communities Initiative ${ }^{31}$ to support projects that reduce natural hazards while emphasizing water quality benefits. Quality of life can be lifted up as a starting point for rejuvenation of a community. EPA's program encourages cross-boundary work including the faith and cultural community as active planning participants in community projects.

One at risk community suggested that a watershed festival hosted by communities distressed by water issues could coincide with the watershed planning that the state has initiated. The festival could link communities along a watershed for

\footnotetext{
${ }^{30}$ Louisiana Watershed Initiative, www.watershed.la.gov

${ }^{31}$ https://www.epa.gov/aboutepa/about-sustainable-and-healthy-communities-research-program
} 
storytelling, food, and faith traditions while celebrating the common source of water. Telling the water's story together is a way to start the relationship building between different people and the trust needed to work on other issues that emerge from the stories. Examples of local community problem-solving through the convergence of people's experienced lifeways, stories, and problematization are abundant (Peterson 2011). Networks organically built around extended family and their practices of food, faith, celebrations, and music provide the building of the connectional web to establish relationships (Park et al. 1993).

Collaboration and asset building work is neither a top-down nor a bottom-up approach to planning and usually multidimensional in scope. The in-between entities sometimes called boundary organizations can act as facilitators, interpreters, and resource advocates. They can help facilitate the linkages for collaborative work and can serve as connectors of resources between and within grassroots, grasstops, and formal organizations, be they academic, philanthropic, or government (Taylor et al. 2012; NASEM 2018). When inter-/intra-organizational connections and relationship are developed and collaboration is established with a non-hierarchal structure, each organization increases in strength and effectiveness. All participating entities can claim the co-ownership of the work and the co-learning process (Laska and Peterson 2011).

A New Plan for Louisiana is to get creative with resources, to think with ingenuity while addressing the issues at hand. Using a process similar to what Bob Becker used for the New Orleans City Park recovery post Katrina could result in creative acquisition of resources for projects and to have projects prepositioned for grants when they are available (Borrup 2006). Addressing a particular issue such as clean water links people of place with each other as an affinity group, regardless if some are natives to the area and others are recent arrivals. The affinity group's interest in a particular topic that is critical to the group's well-being can generate the interest for learning and action. The EPA Healthy Community Program and the Citizen Institute on Rural Design (CIRD) ${ }^{32}$ are national entities that can help in resourcing a community's vision in addressing an issue. Each helps the community build their capacity for well-being. Using a similar strategy as Becker's City Park planning and recovery model would help link these efforts with and to an overall State plan to prioritize and monitor all the components for evaluation and achievement.

Developing "new communities" or rejuvenating fading communities can offer positive outcomes for people still in place and those who want to remain rural in their living orientation, connection to the land. Relying on old ideologies and practices has placed the state on the bottom rung for education, health care, potable water quality, as well as other physical, economic, and social indicators (US News and World Report 2019). It is critical now with the coastal and inland threats to have a vision and to be aspirational; it is possible to have caring capacity through climate land trusts and the full utilization of our cultural assets. Cross-boundary networking

${ }^{32}$ CIRD: www.arts.gov/partnership/citizens-institute-rural-design 
can be enhanced and increased through relationships of established cultural networks to achieve both of these goals.

\subsection{Conclusions}

The approaches shared in this chapter, utilizing the faith and cultural richness of the state, can enhance and celebrate the depth of shared and appreciated values of music, food, family, and faith. The deep-rootedness of various cultural communities has contributed to the food, music, and festival traditions that make Louisiana attractive to tourism. Thus, the biblical notion of sojourner and the reciprocal one of giving of hospitality are keys to how the migration can be framed to achieve a positive acceptance by the receiving communities.

Geographical population shifts can be an opportunity for the state to address dire social, health, and human dimension issues while in the mire of coastal land loss and forced displacement. If all issues are not addressed together, the consequences will likely repeat former patterns of built vulnerability and diminished human capacity (Taylor-Ide and Taylor 2002).

The coordination, knowledge, expertise, and skill sets for creating and hosting a festival of any type "takes a village." The skills used are the same as those used in community planning and simply in community functioning. They can be harnessed as valuable resources in problem-solving. For an inclusive discourse in holistic planning, the participants need to go beyond non-profits, agencies, academics, and business communities to include the arts and faith communities and essential at the core-the people themselves, especially the youth (Taylor et al. 2012; Esteva and Prakash 2014). As witnessed in the work of the Isle de Jean Charles BiloxiChitimacha-Choctaw Tribe resettlement planning process, children and youth were eager to participate in what will be their future (Hart 1997).

Strong cultural and faith traditions are assets often overlooked for problemsolving larger issues such as water, contamination, and relocations (Aldrich and Meyer 2015). Asset-based planning uses community-driven practices, racial equity, transparency, and participation. It also applies accountability in governance of the work process (West et al. 2008). Through formal and informal networks of family and festivities, these affinity groups can help create relationships/friendships and bonds while bringing joyful celebration into problem-solving (Kretzmann and McKnight 1993).

A New Plan for Louisiana must be inclusive and multidimensional, using best principles and wisdom from every knowledge discipline and practice. It must have goals that bring the state's health and well-being up to an exemplar of good living for its people, a caring capacity. And concurrently the plan will need to consider land usage and its benefit for restoring the health of the environment through climate land trusts, while giving a future location for future displaced populations in resettlement. 


\section{References}

Adeniyi, O., Hernandez, A., LeBlanc, M., King, J., \& Janes, M. (2016). Quantitation of pesticide residue in water and food in Louisiana, USA. Journal of Water Resource Protection., 8, 1145-1157. https://doi.org/10.4236/jwarp.2016.812089.

Akuno, K., Hall, S., King, B., \& Nangwaya, A. (Eds.). (2017). Rising, Jackson: The struggle for economic democracy and black self-determination in Jackson, Mississippi. Montreal, Canada: Daraja Press.

Aldrich, D. P., \& Meyer, M. A. (2015). Social capital and community resilience. American Behavioral Scientist, 59(2), 254-269. https://doi.org/10.1177/0002764214550299.

Association of Statisticians of American Religious Bodies (ASARB). (2012). Religious diversity in the United States, 2010. [map] Retrieved from http://www.usreligioncensus.org/images/004. jpg

Ballard, M. (2017, April 8). Across Louisiana, crumbling infrastructure threatens small town water supplies. The Advocate. Retrieved on February 6, 2019 from https://www.theadvocate.com/ acadiana/news/article_8b57ab2c-19fc-11e7-b596-3b474ce3c816.html

Belluz, J. (2016, December 20). We visited one of America's sickest counties. We're afraid it's about to get worse. VOX. Retrieved from https://www.vox.com/2016/12/7/13673802/ louisiana-healthcare-concordia-sickest-counties-in-america

Blackwell, V., Drash, W., \& Lett, C. (2017 October 20). Toxic tensions in the heart of "Cancer Alley." CNN. Retrieved from https://www.cnn.com/2017/10/20/health/louisiana-toxic-town/ index.html

Bolin, R., \& Bolton, P. (1986). Race, religion, and ethnicity in disaster recovery. Program on environment and behavioral science. Boulder, $\mathrm{CO}$ : University of Colorado.

Borrup, T. (2006). The creative community builder's handbook: How to transform communities using local assets art, and culture. St. Paul, MN: Wilder Publishing Center.

Bowen, W. R. (2009). Engineering ethics: Outline of an aspirational approach. London: Springer.

Brasseaux, C., \& Davis, D. (2017). Ain't there no more: Louisiana's disappearing coastal plain. Jackson, MS: University Press of Mississippi.

Brasseaux, C. A., Brasseaux, R. A., \& Bienvenu, M. (2005). Stir the pot: The history of Cajun cuisine. New York, NY: Hippocrene Books.

Brown, L. R. (2011). World on the edge: How to prevent environmental and economic collapse. New York, NY: Earth Policy Institute. W.W Norton \& Company, Inc.

Buber, M. (1970). I and thou. New York, NY: Charles Scribner's Sons.

Bullard, R. D. (1994). Unequal protection: Environmental justice \& communities of color. San Francisco, CA: Sierra Club Books.

Chappelle, S. E., Baker, J. H., Esslingen, D. R., Ridgway, W. H., Schultz, C. B., \& Stiverson, G. A. (1986). Maryland: A history of its people. Baltimore, MD: The John Hopkins University Press.

Citizen's Institute on Rural Design (CIRD). (2018). "About CIRD". Retrieved from https://www. rural-design.org/about

Coles, R. (1987). Dorothy day: A radical devotion. Reading, MA: Addison-Wesley.

Conn, S. (2009). Origins: Guess what? The new deal worked! Retrieved from The Ohio State University and Miami University website: http://origins.osu.edu/history-news/ guess-what-new-deal-worked

Cooperman, A. (2015). U.S. public becoming less religious. Pew Research Center. Retrieved from https://www.pewforum.org/2015/11/03/u-s-public-becoming-less-religious/

Curth, K. (2018, November 12). LA's aging infrastructure: Nearly 2,000 structurally deficient bridges, no money for repairs. Fox8Live. Retrieved from http://www.fox8live.com/2018/11/13/ las-aging-infrastructure-nearly-structurally-deficient-bridges-no-money-repairs/

Cutter, S. L., Ash, K. D., \& Emrich, C. T. (2016). Urban-rural differences in disaster resilience. Annals of the American Association of Geographers, 106(6), 1236-1252. https://doi.org/10.10 80/24694452.2016.1194740. 
Dalbom, C., Hemmerling, S., \& Lewis, J. (2014). Community resettlement prospects in Southeast Louisiana. New Orleans, LA: Tulane University Law School, Tulane Institute on Water Resources and Policy.

Davis, J. E. (Ed.). (2010). The community land trust reader. Cambridge, MA: Lincoln Institute of Land Policy.

Derrida, J. (2000). Of hospitality. Stanford, CA: Stanford University Press.

DeSantis, J. (2019, February 26). Isle de Jean Charles relocation project moves forward; local tribe pushes back. The Times. Retrieved from https://www.houmatimes.com/news/isle-dejean-charles-relocation-project-moves-forward-local-tribe/article_1869106e-3a4e-11e9-bcf3f35bfcbcc033.html

Doherty, G. W. (2004). Crisis in rural America: Critical incidents, trauma and disasters. Traumatology, 10(3), 145-164. https://doi.org/10.1177/153476560401000302.

Edwards, T. (2019, March 28). Personal communication.

Environmental Working Group (EWG). (2015). Tap Water Database. Retrieved from https://www. ewg.org/tapwater/

Escobar, A. (2008). Territories of difference: Places, movements, life, redes. Durham, NC: Duke University Press.

Esteva, G., \& Prakash, M. (2014). Grassroots post-modernism: Remaking the soil of cultures. London: Zed Books.

Foucault, M. (2009). History of madness. New York, NY: Routledge.

Freire, P. (1996). Pedagogy of the oppressed. New York, NY: Continuum.

Fullilove, M. T. (2004). Root shock: How tearing up city neighborhoods hurts America, and what we can do about it. New York, NY: One World Press.

Goodell, J. (2017). The water will come: Rising seas, sinking cities. New York, NY: Little, Brown and Company.

Goulet, D. (1995). Development ethics: A guide to theory and practice. London: Zed Books.

Hart, R. A. (1997). Children's participation in planning. New York, NY: Taylor and Francis.

Harvey, D. (1996). Justice, nature and the geography of difference. Oxford: Blackwell.

Hauer, M. E. (2017). Migration induced by sea-level rise could reshape the US population landscape. Nature Climate Change, 7, 321-325. https://doi.org/10.1038/nclimate3271.

Hawken, P. (2017). Drawdown: The most comprehensive plan ever proposed to reverse global warming. New York, NY: Penguin Books.

Hemmerling, S. A. (2017). A Louisiana coastal atlas: Resources, economies and demographics (the natural world of the Gulf south). Baton Rouge, LA: Louisiana State University Press.

Highfield, W. E., Peacock, W. G., \& Van Zandt, S. (2014). Mitigation planning: Why hazard exposure, structural vulnerability, and social vulnerability matter. Journal of Planning Education and Research, 34(3), 287-300. https://doi.org/10.1177/0739456X14531828.

Hillier, J., \& Rookby, E. (2005). Habitus: A sense of place (2nd ed.). Aldershot, England: Ashgate.

Holley, D. (1940). Uncle Sam's farmers: The New Deal communities in the lower Mississippi Valley. Chicago, IL: University of Illinois Press.

Horney, J., Nguyen, M., Salvesen, D., Dwyer, C., Cooper, J., \& Berke, P. (2017). Assessing the quality of rural hazard mitigation plans in the southeastern United States. Journal of Planning Education and Research, 37(1), 56-65. https://doi.org/10.1177/0739456X16628605.

Howard, E. (1965). Garden cities of to-morrow. Cambridge, MA: The MIT Press.

Hufford, M. (Ed.). (1994). Conserving culture: A new discourse on heritage. Champaign, IL: University of Illinois Press.

Jackson, J. B. C., \& Chapple, S. (2018). Breakpoint: Reckoning with America's environmental crises. New Haven, CT: Yale University Press.

Jones, T. L. (2018, August 5). Black community in flood-prone New Roads area feels pushback form white neighborhood over relocation site. The Advocate. Retrieved from https://www. theadvocate.com/baton_rouge/news/article_ee6b7b88-95db-11e8-a52e-cb57c9ecb7d0.html

Jordan, C. (1972). In D. Lee (Ed.), The substance of faith and other Cotton Patch Sermons. New York, NY: Association Press. 
Kearney, R., \& Semonovitch, K. (2011). Phenomenologies of the stranger: Between hostility and hospitality. New York, NY: Fordham University Press.

Kettering, D. D. (2003, June 30). Dan West Papers. Series 18. Brethren Historical Library and Archives: Goshen College.

Krajeski, R. (2018, July). Framing research: Concepts and jargon in disaster research. Panel presented at Natural Hazards Center workshop: Boulder, CO.

Kretzmann, J. P., \& McKnight, J. L. (1993). Building communities from the inside out: A path toward fighting and mobilizing a community's assets. Chicago, IL: ACTA Publications.

Lash, J. P. (1988). Dealers and dreamers: A new look at the New Deal. New York, NY: Doubleday.

Laska, S., \& Peterson, K. (2011). The convergence of catastrophes and social change: The role of participatory action research in support of the new engaged citizen. Journal of Applied Social Sciences., 5(1, Spring), 24-36. https://doi.org/10.1177/193672441100500102.

Laska, S., Peterson, K., Rodrigue, C., Cosse, T., Philippe, R., Burchett, O., \& Krajeski, R. (2015). Layering of natural and human-caused disasters in the context of sea level rise: Coastal Louisiana communities at the edge. In Disaster's impact on livelihood and cultural survival: Losses, opportunities, and mitigation. Boca Raton, FL: CRC Press.

Lasley, C. B. (2012). Catastrophe and the role of social networks in recovery: A case study of St. Bernard Parish, LA residents after Hurricane Katrina. Unpublished University of New Orleans. Dissertation.

Low, S., \& Lawrence-Zuniga, D. (Eds.). (2003). The anthropology of space and place: Locating culture. Oxford: Blackwell Publishing.

Lowlander Center. (2017). Building the resilience of small coastal businesses. New Orleans, LA: Entergy.

Maida, C. (Ed.). (2007). Sustainability and communities of place. Brooklyn, NY: Berghahn Books.

Maldonado, J. (2018). Seeking justice in an energy sacrifice zone: Standing on vanishing land in coastal Louisiana. New York, NY: Routledge Press.

Malsale, P., Sanau, N., Tofaeono, T., Kavisi, Z., Willy, A., Mitiepo, R., Lui, S., Chambers, L., \& Plotz, R. (2018, December). Protocols and partnerships for engaging Pacific Island communities in the collection and use of traditional climate knowledge: Traditional weather and climate knowledge remains important for environmental decision-making in the Pacific. Bulletin of the American Meteorological Society., 99(12), 2471-2489. https://doi.org/10.1175/ BAMS-D-17-0163.1.

Marsh, B. C. (1909). An introduction to city planning: Democracy's challenge to the American city. Whitefish, MT: Kessinger Publishing, LLC.

Matthei, C. (1992). U.S. land reform movements. The community land trust reader. Cambridge, MS: Lincoln Institute of Land Policy.

Morton, T. (2013). Hyperobjects: Philosophy and ecology after the end of the world. Posthumanities (series 27). Minneapolis, MN: University of Minnesota Press.

Morton, T. (2017). Humankind: Solidarity with nonhuman people. London: Verso.

Morton, C. \& Lagrave, K. (2018). The best cities in the U.S.: 2018 Readers' Choice Awards. Conde Nast Traveler. Retrieved from https://www.cntraveler.com/gallery/best-cities-us

National Academy of Sciences, Engineering, \& Medicine (NASEM). (2018). Understanding the long-term evolution of the coupled natural-human coastal system: The future of the U.S. Gulf Coast a consensus study report. Washington DC: The National Academies Press. https://doi. org/10.17226/25108.

Newman, E. (2007). Untamed hospitality: Welcoming God and other strangers. Grand Rapids, MI: Brazos Press.

Newport, F. (2017). Mississippi retains standing as most religious state. Gallup: Social \& Policy Issues. Retrieved from https://news.gallup.com/poll/203747/mississippi-retains-standing-religious-state.aspx

Nored, R. E. (1999). Reweaving the fabric: How congregations and communities can come together to build their neighborhoods. Montgomery, AL: Black Belt Press.

Ogletree, T. W. (2003). Hospitality to a stranger: Dimensions of moral understanding. Louisville, KY: Westminster John Knox Press. 
Ostrom, E., \& Walker, J. (Eds.). (2003). Trust and reciprocity: Interdisciplinary lessons from experimental research. New York, NY: Russell Sage Foundation.

Park, P., Brydon-Miller, M., Hall, B., \& Jackson, T. (Eds.). (1993). Voices of change: Participatory research in the United States and Canada. Westport, CT: ABC-CLIO.

Peterson, K. (2011). Transforming researchers and practitioners: The unanticipated consequences (significance) of Participatory Action Research (PAR). University of New Orleans Theses and Dissertations. 129. New Orleans, LA.

Peterson, K., \& Krajeski, R. (2011). Grounded in faith, inspired to action: Bayou women own their recovery. In D. Emmanuel \& E. Enarson (Eds.), Women of Katrina: The gendered dimensions of disaster recovery. Nashville, TN: Vanderbilt Press.

Pope, J. (2013, April 10). Bob Becker, City Park's CEO, named a distinguished UNO alumnus. NOLA: The Times Picayune. Retrieved from https://www.nola.com/education/2013/04/bob_ becker_city_parks_ceo_name.html

Reed, G. (2018). A toxic threat: Government must act now on PFAS contamination at military bases [Fact Sheet]. Center for Science and Democracy at the Union of Concerned Scientists. Retrieved from https://www.ucsusa.org/sites/default/files/attach/2018/09/a-toxic-threat-pfsmilitary-fact-sheet-ucs-2018.pdf

Regis, H. A. (2019). Re-thinking subsistence in turbulent times: New contexts, configurations, and intersections with social and environmental justice: Festivals to subsistence and back again. Panel presented at the 79th annual meeting of the Society for Applied Anthropology Conference: Portland, OR.

Rittel, H. W. J., \& Webber, M. M. (1973). Dilemmas in a general theory of planning. Policy Sciences, 4, 155-169. https://doi.org/10.1007/BF01405730.

Rogers, E. M. (2003). Diffusion of innovations. New York, NY: Free Press.

Rom-Shiloni, D. (2013). Exclusive inclusivity: Identity conflicts between the exiles and the people who remained (6th-5th Centuries BCE). The Library of Hebrew Bible/Old Testament Studies Vol. 543. Bloomsbury, NY.

Ruppert, T. (2019, May 7) Keeping history above water: Politics and policy. St Augustine, FL.

Schliefstein, M. (2013, March 19). Louisiana's infrastructure ranks C- for poor roads, dams, drinking water systems. NOLA Times Picayune. Retrieved from https://www.nola.com/politics/2019/03/ broad-street-overpass-bike-lanes-will-feature-new-protections-cyclists-still-wary.html

Scott, J. C. (1990). Domination and the arts of resistance. New Haven, CT: Yale University Press.

Serrv. (n.d.). Our Story. Retrieved from https://www.serrv.org/category/about-us

Smith-Christopher, D. (2002). A biblical theology of exile. Minneapolis, MN: Fortress Press.

Southern Poverty Law Center (SPLC): Active Hate Groups in the United States 2018 [map]. Retrieved from https://www.splcenter.org/hate-map

Steingraber, S. (1998). Living downstream: A scientist's personal investigation of cancer and the environment. New York, NY: Vintage Books.

Swierzewski, R. (2007). Rural philanthropy: Building dialogue from within. Washington, DC: National Committee for Responsive Philanthropy.

Taylor, D. C., Taylor, C. E., \& Taylor, J. O. (2012). Empowerment of an unstable planet: From seeds of human energy to a scale of global change. New York, NY: Oxford University Press.

Taylor-Ide, D., \& Taylor, C. E. (2002). Just and lasting change: When communities own their future. Baltimore, MD: John Hopkins University Press.

The Sustainable Scale Project. (2003). "Carrying Capacity". Retrieved from http://www.sustainablescale.org/ConceptualFramework/UnderstandingScale/MeasuringScale/CarryingCapacity. aspx

Thomas, E. (2014). Planning and building livable, safe \& sustainable communities: The patchwork quilt approach. New Orleans, LA: National Hazards Mitigation Association.

Tierney, K. (2014). The social roots of risk: Producing disasters, promoting resilience. Stanford, CA: Stanford University Press.

Tonnies, F. (2001). Community and civil society. Cambridge: Cambridge University Press.

Tweedlie, S. W. (1978). Viewing the Bible Belt. Journal of Popular Culture, 11, 865-876. https:// doi.org/10.1111/j.0022-3840.1978.1104_865.x. 
UNESCO. (2018). Reshaping Cultural Policies 2018: 2005 Convention Global Report. Paris, France. Retrieved from http://uis.unesco.org/sites/default/files/documents/reshaping-culturalpolicies-2018-en.pdf

University of Wisconsin Population Health Institute: 2018 County Health Rankings. Retrieved from http://www.countyhealthrankings.org/rankings/data/LA

US News \& World Report. (2019). Best states 2019: Ranking performance throughout all 50 states. Retrieved from https://media.beam.usnews.com/69/4f/9ec3a3e94c4080b146d64d272 88a/190508-best-states-overall-rankings-2019.pdf

Walker, B., \& Salt, D. (2012). Resilience practice: Building capacity to absorb disturbance and maintain function. Washington, DC: Island Press.

West, J., Peterson, K., Alcina, M., \& Laska, S. (2008). Principles of participation and issues of entry for Participatory Action Research (PAR) in coastal community resiliency enhancement collaboration. Journal for Community Engaged Research and Learning Partnerships., 1(1). http://www.manifestationjournal.org/.

Wisner, B., Blaikie, P. M., Cannon, T., \& Davis, I. (2004). At risk: Natural hazards, people's vulnerability and disasters. London: Routledge.

Woods, M. (2018, November). Precarious rural cosmopolitanism: Negotiating globalization, migration and diversity in Irish small towns. Journal of Rural Studies, 64, 164-176. https://doi. org/10.1016/j.jrurstud.2018.03.014.

Wright, T. (2019, January 24) Tough choices ahead for Louisiana's struggling water systems. The Lens. Retrieved from https://thelensnola.org/2019/01/24/tough-choices-ahead-for-louisianasstruggling-water-systems/

Wyatt, L. (1983). We are the boat. [Recorded by Folk Legacy Records, Inc.] Roots and Branches. BMI. Greenfield, MA.

Young, I. M. (1990). Justice and the politics of difference. Princeton, NJ: Princeton University Press.

Zelinsky, W. (1972). Cultural geography of the United States. (Foundation of Cultural Geography Series). Upper Saddle River, NJ: Prentice Hall Publishing.

Open Access This chapter is licensed under the terms of the Creative Commons Attribution 4.0 International License (http://creativecommons.org/licenses/by/4.0/), which permits use, sharing, adaptation, distribution and reproduction in any medium or format, as long as you give appropriate credit to the original author(s) and the source, provide a link to the Creative Commons license and indicate if changes were made.

The images or other third party material in this chapter are included in the chapter's Creative Commons license, unless indicated otherwise in a credit line to the material. If material is not included in the chapter's Creative Commons license and your intended use is not permitted by statutory regulation or exceeds the permitted use, you will need to obtain permission directly from the copyright holder.

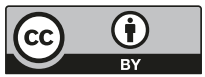

